Derleme

\title{
Dijital Annelerin Feminist Sesi: Annelik İnşasının Tartışmaya Açılmasında Web Siteleri ve Blog İçeriklerinin Rolü
}

\author{
Derya Gül Ünlü (Dr. Öğr. Üyesi) \\ İstanbul Üniversitesi Illetişim Fakültesi \\ derya.gul@istanbul.edu.tr
}

Başvuru Tarihi: 17.10.2020

Yayına Kabul Tarihi: 07.12.2020

Yayınlanma Tarihi: 29.01.2021

https://doi.org/10.17680/erciyesiletisim.811867

\section{Öz}

Kadınların annelik rollerine dair ihtiyaçları doğrultusunda dijital iletişim ortamlarında yer almaya başlamaları, toplumsal yapı tarafından içeriği belirlenmiş annelik rolü gerekliliklerinin yerine nasıl getirileceğine ilișkin içerik üretimini beraberinde getirmiş, böylelikle annelik inşası dijital ortama taşınmıştır. Kadınların dijital iletişim ortamlarında annelik pratikleri hakkında içerik üretip, tüketmeye başlamaları, bu dijital tartışma ortamlarını uygun annelik rolüne ilişkin önerilerin yer aldığı birer annelik modeli sunumuna dönüştürmüş ve kadınların benimseyebileceği örnek annelik uygulamaları hakkında tavsiyeler sunan yeni alanlar ortaya çıkmıştır. Bu odak noktasından yola çıkan çalışmada, annelik rol gerekliliklerine dair üretilen dijital içeriğin annelik inşasının tartışmaya açılması sürecinde nasıl bir rol oynayabileceğinin değerlendirilmesi hedeflenmektedir. Bu hedefe uygun olarak, gerçekleștirilen literatür çalışması içerisinde, dijital annelere yönelik web siteleri ve blog içeriklerinin kadınların feminist sesinin duyurulmasında nasıl bir potansiyele sahip olabileceği ele alınmaktadır.

Anahtar Kelimeler: Dijital İletişim, Dijital Annelik, Web Sitesi, Blog, Feminist Aktivizm. 
Review

\title{
Feminist Voice of Digital Mothers: The Role of Web Sites and Blog Contents in Opening Motherhood Construction to Discussion
}

\author{
Derya Gül Ünlü (Asst. Prof. Dr.) \\ İstanbul University Faculty of Communication \\ derya.gul@istanbul.edu.tr
}

Date Received: 17.10 .2020

Date Accepted: 07.12.2020

Date Published: 29.01.2021

https://doi.org/10.17680/erciyesiletisim.811867

\begin{abstract}
Women's increasing participation in digital communication media due to their needs related to motherhood roles was accompanied by the production of content on the pre-determined requirements of motherhood role, thereby carrying the construction of motherhood to digital media. As women start to produce content about maternity practices on digital media, such digital media each turned into a presentation of motherhood model where suggestions related to appropriate motherhood role are provided, and new domains that bring forward suggestions about motherhood practices emerged. Based on this focus, the study aims to evaluate what role the digital content produced on maternity role requirements can play in the process of opening maternity construction for discussion. In line with this goal, the literature study examines the potential of websites and blog contents for digital mothers in promoting women's feminist voices.
\end{abstract}

Keywords: Digital Communication, Digital Motherhood, Web Site, Blog, Feminist Activism. 


\section{Giriş}

Günümüzde annelik rollerine ilişkin ihtiyaçları doğrultusunda dijital ortamdan yararlanan kadınlar, aile içerisindeki rol gerekliliklerini yerine getirebilmek için bilgi aramak ya da kendi günlük pratikleri hakkında diğerine bilgi verebilmek amacıyla dijital içeriği üretmekte ve tüketmektedirler. Dijital anneler tarafından annelik rolünün gereklilikleri hakkında üretilen bu dijital içerik, kadınlara nitelikli bir 'annelik görevi' için yerine getirilmesi gereken pratiklerden oluşmaktadır. Söz konusu pratikler aracılığıyla hem anneler kendi günlük rutinlerini ve benimsedikleri annelik modellerini ${ }^{1}$ diğer annelerle paylaşmakta, hem de annelik rolüne ilişkin uygulamaları dijital iletişim ortamlarında tartışmaya açmaktadır. Şüphesiz kadınların annelik rol içeriklerine dair dijital iletişim araçlarından yararlanmaları onların günlük yaşam deneyimlerini kolaylaştırmaktadır. Ancak dijital iletişim ortamlarında anneler tarafından aktarılan bu 'örnek annelik' pratikleri, modern anneliğin dijital ortamlardaki aktarım biçimleri üzerine düşünülmesini de gerekli kılmaktadır. Çünkü anneliğe ilişkin doğal kabul edilen norm ve değerlerin önceleri toplumsal, ekonomik ve tarihsel olarak inşa edildiğinin bilinmesinin yanı sıra, dijitalleşmenin teknolojik bir inşayı da beraberinde getirdiği görülmektedir (Orton-Johnson, 2017, s. 3). Bu bakımdan, dijital iletişim ortamları içerisinde kadınların ürettikleri ve üzerine tartıştıkları içeriklere bağlı olarak, kendi annelik rollerini nasıl inşa ettiklerinin anlaşılması da önemlidir.

Bilindiği üzere annelik, sadece doğurmakla ilgili bir edinimi değil, aynı zamanda toplumsal beklentilerle idealize edilerek inşa edilen bir toplumsal rolü de ifade etmektedir. $\mathrm{Bu}$ toplumsal idealleștirme süreci ise, anneliğin kadının yaratılıșı gereği doğal ve kadınlığının ayrılmaz bir parçası, içgüdüsel bir duygu, kadına bahşedilmiş en değerli, ayrıcalıklı görevi olduğuna ilişkin söylemlerin farklı formasyonlarda yeniden inșa edilerek, sunulmasını kapsamaktadır (Gezer-Tuğrul, 2018, s. 71). Ayrıca, yine bu idealleştirme süreci içerisinde kadının benimsediği annelik modelinin topluma yeni katılan her bir birey üzerinde, özellikle de belirli bir yaşa gelene kadar, önemli bir belirleyiciliği bulunmaktadır. Söz konusu annelik modelleri, toplumsal beklentilere uygunluğu çerçevesinde değerlendirilmekte, diğer kadınlar tarafından kutsanmakta ya da eleştirilmektedir. Toplumsal cinsiyet rolleri temelinde kadınlara ve erkeklere verilmiş olan cinsiyet rol kalıpları kadınların anneliği öğrenmelerine ve buna göre davranmalarına sebep olmaktadır. Bu rollere aykırı davranıldığı takdirde ise, toplumsal baskı mekanizmaları tarafından kadının en kutsal rolü olarak sunulan annelik rolü, hatırlatılmakta ve kadınlığı sorgulanmaktadır (Gezer-Tuğrul, 2018, s. 72). Bu bakımdan değerlendirildiğinde, dijital iletişim ortamlarında kadınlar tarafından üretilen ve tüketilen içeriğin de, toplumsal yapı tarafından kadınlara atfedilerek, kutsanan annelik rolüne ilişkin yansımalara sahip olacağını söylemek yanlış olmayacaktır. Çünkü kadınların annelik pratiklerine yönelik amaçlar doğrultusunda dijital iletişim ortamlarında yer almaya başlamaları, annelik rolü anlatılarının bu ortamlar aracılığıyla yaygınlaştırılması anlamına gelmektedir. Diğer yandan, dijital iletişim ortamlarının kadınlara annelik pratiklerini tartışabilecekleri yeni bir alan sunduğu da görülmektedir. Bu nedenle dijital ortamda birbirleriyle fikir alışverişinde bulunan kadınların, çevrimiçi platformlarda ürettikleri ve tükettikleri annelik pratiklerine ilişkin içeriğin annelik inşasının tartışmaya açılmasında nasıl bir rolünün olabileceği üzerinde durulması da önemli bir gereklilik olarak karşımıza çıkmaktadır. Dolayısıyla çalışma, web siteleri ve bloglarda annelik rol gerekliliklerine dair üretilen dijital içeriğin annelik inşasının tartışmaya açılması sürecindeki rolünün değerlendirilmesini hedeflenmekte ve kadınların bu ortamlardaki paylaşımları aracılığıyla geleneksel annelik rollerinin sorgulanıp sorgulanamayacağına 
ilişkin mevcut literatür üzerinden bir çıkarım ortaya koymayı amaçlamaktadır. Ayrıca dijital annelere yönelik web siteleri ve blog içeriklerinin kadınların feminist sesinin duyurulmasında nasıl bir potansiyele sahip olabileceği de ele alınmaktadır. Bu kapsamda, öncelikle dijital annelik kavramı ele alınarak, kadınların dijital iletişim ortamlarında ürettikleri içeriğe bağlı olarak feminist seslerini yükseltip yükseltemeyeceklerine ilişkin görüşlere yer verilecek, sonrasında ise, web siteleri ve blog içeriklerinin feminist sesin yükselmesinde nasıl bir rol oynayabileceği üzerinde durulacaktır.

\section{Dijital Annelik}

Annelik, geleneksel olarak biyolojik kadınlıkla birlikte anılan ve içi kültürel olarak farklı niteliklerle doldurulan bir kavramdır, ancak en genel anlamıyla anneliği bir çocuğa hamile kalmakla başlayan bedensel bir deneyim ve doğumun ardından bebeğin fiziksel ve psikolojik ihtiyaçlarını karşılamak ekseninde devam eden bir rol olarak tanımlamak mümkündür (Miller, 2010, s. 33). Günümüzde neredeyse çocuğa hamile kalınmadan önce başlayan ${ }^{2}$, tüm hamilelik sürecini kapsayan ve çocuğun her türlü fiziksel ve psikolojik bakımının üstlenilmesini içeren annelik rolü, kadınların üstlendiği tam zamanlı aile içi görevler bütününden oluşmaktadır. Bununla birlikte günümüzün annelerini geleneksel annelik rolünü benimsemenin yanı sıra günlük hayatın gerekliliklerine de uyum sağlayabilen kendisine, eşine, çocuklarına, sosyal çevresine fazlaca zaman ayırabilen yetkinliğe sahip kadınlar olarak tanımlamak da yanlış olmayacaktır. Burada bahsedilen donanımlı anneliği Sever (2014, s. 74) şöyle aktarmaktadır: "Günümüzün 'iyi anneleri' șefkatli ve fedakar olma gibi geleneksel annelik kodlarını korurken, hakim ilerlemeci ve bilimselci söylem uyarınca anneliğini de 'çağın bilgisine' uyduran anneleri temsil etmektedir".

Günümüzün donanımlı ve modern annelerinden hem geleneksel annelik rollerini yerine getirmeleri, hem de çağın gerekliliklerine ayak uydurabilmeleri ve bu süreçte kişisel bakımlarını da aksatmamaları beklenmektedir. Bu kadınlar, anneliği daima birinci planda tutmalı ve kariyerlerini de 'başarıyla yürütürken bakım yapmayı unutmamalı, doğumdan sonra kendilerini 'salmamalı', 'kadınlık vazifelerini' yerine getirmeyi ihmal etmemeli, ayrıca daima sevecen ve sabırlı kalabilmelidir (Sever, 2014, s. 79). Günümüzde kadınların bu toplumsal beklentileri karşılama sürecindeki en büyük yardımcılarından birinin ise, dijital iletişim ortamları olduğunu söylemek yanlış olmayacaktır. Çünkü bahsedilen bu görev ve beklentiler bütününü yerine getirmekle sorumlu olan kadınlar, günlük pratiklerini kolaylaştırmak için dijital ortamın kendilerine sunduğu çok sayıda olanaktan yararlanmaktadır. Kadınların bu donanımlı annelik rolleri için dijital ortamda yer almaya başlamaları, annelik pratikleri ve annelik modelleri hakkında çok sayıda dijital içeriğin üretimini de beraberinde getirmiş, sadece annelik rolleriyle ilgili içeriğin yer aldığı web sayfaları, bloglar, sosyal medya hesapları ve mobil uygulamalar ortaya çıkmıştır. Böylelikle günümüzde anneler, dijital iletişim ortamlarını ebeveynlik pratiklerinin bir parçası olarak kullanabilme, kendi kişisel deneyimlerine ilişkin detayları paylaşabilme, bilgi ve destek arama gibi ihtiyaçlarını giderebilme (Lupton, Pedersen ve Thomas, 2016) imkanını elde etmiştir. Dijital iletişim ortamlarının sunduğu bu çoklu-işlevle birlikte, kadınlar, artan bir biçimde, ebeveynlik pratikleri hakkındaki bilgileri çevrimiçi ortamlarda aramakta ve bu pratiklerin yerine getirilme biçimi, önemi ve hatta gerekliliği üzerine tartışmaktadır. Dolayısıyla dijital teknolojilerin, bir anlamda, annelik deneyimini ve annelik anlatılarını aktararak, annelik pratiği, kimliği ve hikayelerinin yeniden tanımlanabileceği ya da tartışmaya açılabileceği önemli yeni alanlar açtığını da söylemek olanaklıdır (OrtonJohnson, 2017, s. 3). 
Bununla birlikte, dijital iletişim ortamlarındaki annelik pratiklerinin üretim biçimi ve içeriği göz önünde bulundurulduğunda; (1) kadınların ebeveynlik pratikleri hakkındaki dijital içerik üretimini birincil olarak üstlendiği, (2) kadınların annelik rollerine dair dijital içerik üretirken kendilerini toplumsal cinsiyet rollerine ilişkin beklentiler doğrultusunda denetlediği söylenebilir. İlk olarak, ebeveynlik rollerine ilişkin bilgi ve tavsiyeler içeren çok sayıda farklı dijital iletişim ortamının ilk örneklerini annelik pratikleriyle ilgili içerikler üzerinden verdiği ve dolayısıyla bu içeriklerin genellikle anneliğe dair bilgi ve önerileri kapsadığı görülmektedir. Çünkü dijital iletişim ortamlarında okuyuculara ebeveynlik rolüne ilişkin bilgi ve tavsiyeler sunan içerikler, öncelikle anneler tarafından annelik rolleri hakkındaki içerikleri aktaran mecralar olarak ortaya çıkmıştır. Bu bakımdan, ebeveynlik rolleri hakkındaki dijital içeriğin temelde annelik rolüne dair öneri ve tavsiyeler üzerinden kurgulandığını belirtmek olanaklıdır. Yani, kadınların toplumsal hayat içerisinde kendilerinden beklenen donanımlı annelik rolleri çerçevesinde, ev içerisindeki ebeveynlik sorumluluğunu üstlendiklerini ${ }^{3}$; bu sorumluluğu yerine getirmek için dijital iletişim ortamlarından yararlanırken ürettikleri dijital içerik dolayısıyla günümüzde ebeveynlik rollerine ilişkin içeriğin de büyük bir çoğunluğunu yönlendirdiklerini söylemek mümkündür.

Diğer yandan, kadınların dijital ortamlarda diğerleriyle kişisel annelik hikayelerini paylaşırken bir biçimde kendi içeriklerini denetledikleri görülmektedir. Sever'e (2014, s. 81) göre bu durum, annelerin dijital ortamlarda kendilerini korunmasız hissetmeleri, özellikle toplum tarafından dışlanmaktan korktukları için kendilerine otosansür uygulamaları, iyi birer anne olarak görülmemekten çekinmelerinden kaynaklanmaktadır. Bu durum, bir anlamda, annelik rolünün gereklerine ilişkin yeni bir tartışma ortamı sunan çevrimiçi ortamların içeriğinin de kullanıcılar tarafından toplumsal cinsiyet beklentileri doğrultusunda şekillendirilmesine neden olmaktadır. Bu çerçevede Rashley (2005, s. 58), tıpkı ebeveynlik pratiklerini inşa eden geleneksel kaynaklar (aile, sosyal çevre, tavsiye kitapları) gibi, çevrimiçi ebeveynlik kaynaklarının da sadece çocuk yetiştirme hakkında öneriler içermediğinin, aynı zamanda ebeveynlik rolleri hakkındaki cinsiyetlendirilmiş beklentiler sunduğunun altını çizmektedir.

\section{Dijital İletişim Ortamlarında Feminist Ses: Olanaklar ve Engeller}

Dijital iletişim ortamları, yapısı itibariyle, kadınlara kendi toplumsal konumlarıyla ilgili fikirlerini ya da rahatsızlıklarını diğer kadınlara kolaylıkla duyurabilmeleri için bir alt yapı sağlamaktadır. Bu açıdan değerlendirildiğinde, söz konusu ortamların kadınların kendi konumlarını iyileștirebilmek için feminist seslerini duyurabilecekleri bir dönüşüme sahne olabileceklerini söylemek mümkündür. Dijital ortam, özellikle feminist aktivizm hareketlerinin duyurulması, tanıtılması ve bu konudaki duyarlılığın arttırılması açısından kadın kullanıcıların kendi toplumsal konumlarına ilişkin sorgulamalarını kamusallaştırmalarına imkan tanımaktadır. Dolayısıyla önceleri feminist yayınlara erişimi ya da alanlara gidebilmesi olmayan kadınların karşılaştıkları engellerin azalarak, bilgi ve dayanışma elde edebilme olanaklarının arttığı görülmektedir. Günümüzde etiketler ya da hashtagler aracılığıyla kadınlar bir konudaki rahatsızlıklarını dünyanın çok farklı bölgelerindeki kadınlarla paylaşabilmekte, dijital imza kampanyalarına katılabilmekte ve o konuya tepki gösteren diğer kadınlara destek verebilmektedir. Bu bakımdan feminist amaçlar için kullanılan dijital ağlar, hem kullanıcıların birbirleriyle bağlantıda kalmalarını hem de gerçekleştirilen aktivitelere yeni bireylerin katılmasını sağlamaktadır (Fotopoulou, 2016, s. 992). 
Dijital platformların feminist alanları genişletmek için kullanılması, feminizmi ve feminist idealleri daha geniş ve daha açı bir alanda destekleyebilmeyi olanaklı kılmaktadır (Crossley, 2015). Kadınların bu feminist tartışmaya katılımı ise, çevrimiçi ortamlarda toplumsal cinsiyet konuları ile çok sayıda başka sosyal sorun arasında da ilişki kurulabilmesini, böylelikle farklı sınıfsal, etnik ve dinsel kökenden kadının da kolaylıkla buluşmasını sağlamaktadır. Bu özelliği bakımdan çevrimiçi platformların, ana akım feminizm tarafından önemsenmediği iddia edilen seslerin güçlenmesini sağlama potansiyelini de taşıdığı söylenebilir (Kaya, 2018, s. 564-565). Ayrıca yine çevrimiçi platformlar aracılığıyla dolaşıma sokulan söylemler, değerler ve ideolojiler toplumsal cinsiyet temelli siyasal aktivizmin ağ tabanlı bir imgesel feminizm oluşumuna katkı sağlamaktadır. Yani ağ tabanlı feminizm ve dijital kız kardeşlik ${ }^{4}$, kadın örgütlenmeleri arasındaki iletişimsel pratikleri dönüştürme potansiyelini de taşımaktadır (Fotopoulou, 2016, s. 989).

Buna ek olarak, dijital ortamların özellikle genç kadınların feminist harekete katılımının ve üçüncü kuşak feminizm dayanışmasının güçlenmesi açısından büyük önem taşıdığını söylemek gerekmektedir. Dijital tartışma ortamları aracılığıyla genç kadınlar, çevrimiçi ortamlarda hem birbirlerine destek olmakta hem çeșitli politik olayları tartışmakta hem de gerçek dünyadaki etkinlikleri organize edebilmektedir. Bu bağlamda Schuster ${ }^{5}$ (2013, s. 8), dijital iletişim ortamlarının esnek, ucuz, ulaşılabilir ve geniş gruplara erişilebilir olması bakımından genç feminist kadınlar tarafından değerli görüldügünden bahsetmektedir. Bununla birlikte araştırmacı (2013, s. 16), genç kadınların dijital iletişim ortamlarını, sadece günlük siyasal içerikli olmayan iletişim için değil, aynı zamanda feminist aktivitelere yönelik haber alabilecekleri güncel bir bilgi kaynağı olarak kullandıklarını da belirtmektedir. Ayrıca dijital iletişim teknolojileri akışkan ve çok çeşitli bir niteliğe sahip olan üçüncü dalga feminizm hareketine katılımı da kolaylaştırmakta, çevrimiçi ortamlarda genç kuşak kadınlara dair yeni bir kültürel üretime temel oluşturmaktadır (Keller, 2012, s. 433). Bu çerçevede çevrimiçi ortamların genç kuşak kadınlara feminist aktivizm için yeni yollar önerdiği ve dijital bir kız kardeşlik kurulmasına olanak tanıdığı da görülmektedir. Dijital kız kardeşlik, kadınlara dijital bir dayanışma ortamı sunması bakımından oldukça önem taşımaktadır. Konuyla ilgili olarak, genç kadınlar feminist harekete katılmaları nedeniyle karşılaştıkları problemler yüzünden 'gerçek dünyalarında' konuşacak akran bulamadıklarından ve yaşadıkları izole edilmiş olma hissini dijital ortamlar aracılığıyla giderdiklerinden bahsetmektedir. Ayrıca kadınlar, yaşadıkları çeşitli cinsel taciz, aşağılanma gibi travmatik deneyimlerini dijital ortamda karşılaştıkları kendileri gibi benzer hikayelere sahip diğerleriyle paylaşabilmekte, 'gerçek dünyanın' tersine kimlikleriyle ilgili bilgiyi de kendi istedikleri ölçüde açıklayabilmektedir (Schuster, 2013, s. 17-18).

Diğer yandan, dijital ortamların feminist hareketin duyurulması, feminist hareketlere katılım düzeyi ve katılanlar arasındaki dayanışmanın sağlanması sürecinde kadınlar arasında bir eşitsizliğe neden olduğu da tartışılmaktadır. Dijital ortamın yapısı dolayısıyla ortaya çıktığından bahsedilen bu engelleri ise, şöyle sıralamak mümkündür: (1) tüm kadınlar için dijital ortama eş düzeyde erişimin imkansızlığı, (2) dijital ortamda karşılaşılan eleștiriler, (3) kullanıcı eğilimlerinin dijital ortamda karşılaşılan feminist içeriği belirlemesi. Bilindiği üzere, her ne kadar günümüzde internet erişimi oldukça yaygınlaşmış olsa da, dünyanın farklı bölgelerindeki tüm kadınların çevrimiçi ortama eş düzeyde erişiminin sağlanması mümkün değildir. Bu durum, birçok şeyde olduğu gibi feminist aktivizme katılımda da eksiklik ve dengesizliğe yol açmakta, bu da 
sesini duyurmaya çalışan kadınlar arasındaki ırksal ve sınıfsal eşitsizliğe bir yenisini eklemektedir. Dijital tartışma ortamlarında sadece belirli ırk ve sınıfa mensup kadınların yer alması ise, ele alınan sorun ve eşitsizliklerin, dijital ortamlara erişim imkanı olan bireylerin gündemleri ve ilgi alanları üzerinden tartışmaya açılmasına neden olmaktadır (Keller, 2012). Söz konusu feminist tartışmanın yayılmasındaki bir diğer önemli engel de dil bariyeridir. Her ne kadar dijital iletişim ortamları dünyanın her yerinden kadınların erişimine ve birbirleriyle etkileşimlerine olanak sağlasa da dil bariyeri kadınların dünya genelinde ortak bir tartışmayı sürdürebilmesini imkansızlaştırmaktadır. Dolayısıyla dijital iletişim ortamlarında bir araya gelen kadınlar, yalnızca kendi ülke ya da bölgelerinde kendileriyle aynı dili konuşan kadınların yer aldığı bölgesel tartışmalara katılabilmektedir. Dil bariyerine takılmayan kadınların ise, dilini konuştukları kadınlarla aynı gündemi paylaş(a)mamaları nedeniyle yalnızca hastaglerin ya da ilgili resimlerin paylaşılması aracılığıyla desteklerini gösterdikleri, ortak bir tartışma içerisinde yer alamadıkları görülmektedir.

Tüm bunların yanı sıra dijital iletişim ortamlarında feminist aktivizm hareketlerine katılan ve fikirlerini ifade eden kadınların, diğer kullanıcılar tarafından zaman zaman çok ciddi eleștirilere maruz kaldıkları da görülmektedir. Bu bağlamda Schuster (2013, s. 19), kadınların çevrimiçi ortamlarda düşüncelerini ifade ederken sert eleştirilerle ya da çevrimiçi tacizle karşılaşmalarının gelecekteki feminist hareketlere katılımı azaltabilecek olduğundan bahsetmekte ve bu nedenle feminist aktivizme katılımda çevrimiçi araçların kullanımının feminist hareketi zayıflatan bir etkisinin olabileceğini ileri sürmektedir. Bu perspektiften değerlendirildiğinde, araştırmacının haklılık payı olmakla birlikte, kadınların geleneksel aktivist hareketlerde yer alırken karşılaştıkları saldırılarla kıyaslandığında dijital eleştiri ya da tacizlerin çok da yıldırıcı olmayabileceği düşünülmekte, ancak bu durumun kadınların düşüncelerini özgürce ifade etmelerinin önünde bir engel oluşturacağını da eklemek gerekmektedir.

Son olarak, kullanıcı kaynaklı olmayan ancak feminist sesin yükselmesini engelleyen sosyal ağların yapısına da değinmek önem taşımaktadır. Bahsedilen bu durum, kullanıcıların bireysel takip etme eğilimlerine uygun içeriklerle karşılaşmalarından kaynaklanmaktadır. Sosyal medya ortamları, bireye 'kişiye özel' bir deneyim sunduğundan, tüm kullanıcılar için ortak bir tartışma ortamı oluşmasını engellemekte, bu da herkesin içinde yer alabileceği bir feminist tartışma ortamının var olamamasına neden olmaktadır (Schuster, 2013, s. 20). Ayrıca kullanıcıların tüm paylaşımları takip ederek, tüm aktivitelerden haberdar olmaları, aktif bir sosyal medya kullanıcısı olmalarına bağlıdır. Bu durum da, feminist aktivitelerle ilgili bilgi sahibi olma açısından aktif ve pasif sosyal medya kullanıcıları arasında bir farklılaşma yaratmaktadır.

\section{Dijital Anneler ve Feminist Ses}

Anneler, dijital iletişim ortamlarında yer alan içeriği hem annelik rollerinin gereklilikleri doğrultusunda kullanmakta hem de kendi günlük pratiklerinden yola çıkarak paylaştıkları deneyimleri aracılığıyla çevrimiçi ortamlardaki annelik önerilerini çeşitlendirmektedir. Söz konusu çevrimiçi ortamların en önemlileri arasında ise, anneler için dijital içerik üretimi ve tüketimine olanak tanıyan web siteleri ve bloglar sayılabilir. Dijital anneler, web siteleri ve bloglarda yer alarak, farklı arka planlardan (demografik özellikler ve feminist bilgiye sahip olma derecesi açısından) gelen kadınları bir arada toplamakta, ortak gündemler üzerinden kişisel annelik modellerini diğer kadınlarla paylaşmakta ve bu modeller hakkında fikir alışverişinde bulunmaktadır. Böylelikle dijital içeriği üreten ve tüketen anneler, sadece bilgi edinmenin dışında birbirleriyle etkileşim kurma ve 
kendi toplumsal konumlarına bağlı olarak karşılaştıkları ortak sorunların tartışıldığı bir ortamda yer alma imkanına sahip olmaktadır. Bu söz konusu ortamda, anneler kendi günlük pratikleri ya da üstlendikleri annelik rolünün gerekliliklerine dair fikir ve eleştirilerini anonim bir biçimde ifade edebilmektedir. Ayrıca anonimliğin yanı sıra finansal sıkıntılar yaşayan kadınlar için de çevrimiçi tartışma ortamları, kadınların feminist hareketten kopmamalarını sağlaması açısından önemlidir. Maddi sıkıntı içerisinde bulunan birçok anne, feminist hareketi desteklemek için harcama yapmaktan (doğrudan para yardımı yapmak ya da etkinliğe katılabilmek için yol parası, giriş ücreti ödemek gibi) çekinebilmektedir. Gerçekleştirilen çevrimiçi ücretsiz etkinlikler kadınların katılımını kolaylaştırmakta, böylelikle kadınlar feminist hareketi desteklemeye daha fazla istekli olmaktadır. Bu bağlamda Schuster (2013), genç annelerin 'gerçek dünyadaki' feminist etkinliklere zaman kısıtı, yoğun tempoları ya da maddi imkansızlıkları dolayısıyla katılamadıklarından bahsetmekte, bu nedenle interneti feminist etkinliklere katılımda bir firsat alanı olarak tanımlamakta ve kadınların internet aracılığıyla feminist etkinlerde daha kolay yer alabildikleri ifade etmektedir.

Dijital ortamın anneler tarafından kullanılmasıyla birlikte, feminist dijital içeriğin yaygınlaştırılması aracılığıyla annelik rolüne ilișkin bir dönüșümün bașlayabileceğini ummanın da olanaklı olduğu düşünülmektedir. Çünkü geleneksel annelik rol gereklilikleri hakkındaki toplumsal beklentinin değiștirilmesi; kadınların günlük rutinlerinde bu gerekliliklerin dışına çıkmaları, geleneksel olmayan pratiklerini diğer kadınlarla paylaşmaları ve neyin gerekli olduğunu birlikte sorgulamalarıla mümkündür. Bu bakımdan, dijital iletişim ortamları aracılığıyla kadınların farklı annelik modellerinin nasıl üstlenildiğini ve bu roller çerçevesinde hangi pratiklerin gerçekleştirildiğini görebilme imkanı elde etmeleri, anneliğe dair neyin gerekli olduğunun sorgulanabilmesi için önemli bir adım olacaktır. Bu doğrultuda, aşağıda, dijital annelerin web siteleri ve annelik blogları üzerinden ürettikleri ve tükettikleri içerikler aracılığılyla geleneksel annelik rollerinin tartışmaya açılıp açılamayacağına ilişkin tartışma ele alınmaktadır.

\subsection{Web Siteleri}

Web siteleri, genellikle hamilelik süreci, doğum ve ebeveynlik hakkında okuyuculara bilgi ve öneriler sunmakta ve site kullanıcılarının tartışma panoları aracılığıyla birbirleriyle sohbet edebilmelerine olanak sağlamaktadır. Söz konusu ortamlarda, kadınlar, kendileriyle benzer durumda olan diğer kadınlarla anonim biçimde iletişim kurabilmekte ve deneyimledikleri sorunlar hakkında bilgi ve tavsiye alabilmekte ya da aktarabilmektedir. Kadınlar arasında gerçekleșen bu paylaşım ve dayanışma, anneler ya da anne adaylarının kendilerine dair kişisel içerikleri diğerlerine açmalarını da beraberinde getirmekte (Lupton ve Pedersen, 2016; Pedersen ve Lupton, 2016), böylelikle her kadının üstlendiği annelik rolüne dair günlük deneyimleri kolaylıkla aktarılabilir olmaktadır. Ayrıca web sitelerinin kullanıcıya sunduğu anonimlik hali, annelerin kendileri hakkında ailevi sorunlar ya da annelikten beklentiler gibi oldukça kişisel içerikleri paylaşmalarını da olanaklı kılmakta (Madge ve O’Connor, 2006; Pedersen, 2014; Schoenebeck, 2013), böylelikle anneler ihtiyaç duydukları sosyal desteğe ulaşabilmekte ve çeşitli sorunları hakkında fikir alışverişinde bulunarak kendilerini rahatlatacak bir platformda yer alabilmektedir (Martland ve Rothbaum, 2006; Radey ve Randolph, 2009).

Kadınların, web siteleri ve çevrimiçi tartışma odalarında, ortak deneyimleri üzerine fikir alışverişinde bulunmalarının anneliğe ilişkin feminist bir sorgulamayı beraberinde getirebileceği düşüncesi; annelerin diğer kadınların annelik rollerini deneyimleme fırsatı elde etmelerinden kaynaklanmaktadır. Çünkü anneler, birbirleriyle gerçekleştirdikleri 
paylaşımlar ve fikir alışverişleri sayesinde, yaşadıkları annelik deneyimini farklı perspektiflerden görebilme, sorunlarına ilişkin çeşitli tavsiyeler alabilme ve diğer kullanıcıların paylaşımları üzerinden anneliğin farklı versiyonlarını gözlemleme olanağına sahip olmaktadır (Johnson, 2015; Madge ve O'Connor, 2005; Pedersen ve Lupton, 2016; Philips ve Broderick, 2014). Bu durumda ise, söz konusu ortamlarda kadınlar tarafından aktarılan annelik pratikleriyle ilgili içeriğin iyi, yoğun, ideal annelik gibi annelik modellerinden hangi annelik modelini pekiştirici bir işleve sahip olduğu önem kazanmaktadır. Bu nedenle ancak geleneksel annelik temsiline aykırı olan içeriklere sahip web sitelerinin annelik rolüne ilişkin beklentileri dönüştürebilecek nitelikte olacağını söylemek yanlıș olmayacaktır. Söz konusu web sitelerini "radikal annelik siteleri" olarak adlandıran Koeber (2001, s. 211), web sitelerinin ${ }^{6}$ kadınların çevrimdışı dünyada hem annelik hem de feminizmle ilgili rahatsızlık duydukları söylemleri tartışabildikleri alanlar yarattığını ve bu alanlarda açıklanan anneliğin radikal feminist temsilinin var olan toplumsal düzeni alt üst edebilecek potansiyele (2001, s. 238) sahip olduğunu öne sürmektedir. Yani Koeber'in ifadesiyle, radikal annelik siteleri, kullanıcılarına geleneksel ebeveynlik düşüncesine direnmek için de kullanılabilecek stratejiler sunmaktadır.

Koeber'in yanı sıra, ebeveynlik rollerine dair içerik sunan web sitelerindeki tartışma ortamlarının feminizmin sesinin yükseltilmesi açısından önem taşıdığını ve kadınların bu ortamlar aracılığıyla fikir alışverișinde bulunarak annelik rolünün gereklerine ilişkin sorgulamayı başlatabileceklerini vurgulayan başka araştırmacılardan da bahsetmek mümkündür (Lopez, 2009; Pedersen ve Smithson, 2013). Örneğin; Lopez (2009, s. 736), web sitelerinin hem kadınların seslerini yaymalarına hem de bu sesi destekleyecek topluluğun oluşmasına imkan tanıyan bir ortam olarak ele alınması gerektiğini vurgulamakta ve web sayfalarında üretilen içeriğin nelerden bahsettiğiyle daha çok ilgilenilmesinin önemi üzerinde durmaktadır. Rashley (2005: 58) ise, web sitelerinde annelik rolü ve pratiklerine ilişkin içerik sunan çevrimiçi materyallerin ebeveynliğe dair sorular için destek sağlamada basılı materyallerin yerini almaya başladığından ve bu nedenle de web sitelerinin feminist eleştiri için önemli birer yeni kaynak sağlayıcılarına dönüștügünden söz etmektedir.

Diğer yandan web siteleri ve çevrimiçi tartışma odalarının, bazı araştırmacılar tarafından ebeveynliğe ilişkin geleneksel cinsiyet kalıpyargılarını desteklemesi nedeniyle eleştirildiği de görülmektedir (Ammari ve Schoenebeck, 2015; Bradly ve Guerin, 2010; Gül-Ünlü, 2019; Madge ve O'Connor, 2006; Rashley, 2005). Örneğin; Rashley (2005), "BabyCenter" isimli web sitesi üzerinden gerçekleştirdiği araştırmasında, ebeveynlere yönelik içeriklerin toplumsal cinsiyet rollerini yansıttığını; çocuk bakımıyla ilgili içeriklerin daha çok annelere hitaben aktarıldığını ortaya koymuştur. Benzer biçimde, Türkiye'de, GülÜnlü (2019) tarafından Bebek.com isimli web sitesi üzerine gerçekleştirilen çalışmada da anne ve babalara hitap eden web sitesi içeriklerinin toplumsal cinsiyet rollerini yansıtacak bir biçimde sunulduğu bulgulanmıştır. Dolayısıyla web siteleri, dijital annelere toplumsal cinsiyet rollerine dayanan örnek annelik içerikleri sundukları ve okuyucuları bu örnek anneliğin nasıl daha iyi yerine getirilebileceğine ilişkin bir tartışmaya yönlendirdikleri gerekçesiyle eleştirilmektedir. Bu bakımdan, web sitelerindeki içeriğin kadınlara ne söylediğinin, web sitelerinin tartışma ortamı sunmasından daha büyük bir öneme sahip olduğu yorumunu yapmak yanlış olmayacaktır. Çünkü dijital annelere sunulan içerik, web sitesi içerisinde üzerine tartışllacak gündemi de belirlemektedir. Tabii ki bu aşamada dijital anneleri tamamen pasif bir konumda değerlendirmek mümkün değildir. Kadınlar aile içi rolleri ve üstlendikleri annelik modeline bağlı olarak birçok web sitesi 
arasından tercih yapmakta ve ihtiyaçları doğrultusunda bilgi ya da tavsiye aramaktadır. Fakat ebeveynlik rolleri hakkında bilgi veren web sitelerinin aslında temel toplumsal cinsiyet rollerini inşa eden nitelikteki içeriği göz önünde bulundurulduğunda, söz konusu tartışma ortamının feminist bir tartışmayı beraberinde getir(e)meyeceği de aşikardır. Dijital annelere sunulan web sitesi içeriklerinin feminist perspektiften uzak olması ya da toplumsal cinsiyet rolleri doğrultusunda yapılandırılması (örneğin; kadınlara doğru emzirme yöntemleri ya da bebeğin mamasında hangi sebzelerin koyulması gerektiği hakkında bilgi verilirken, erkeklere çocuklarıyla en iyi futbolu nerelerde oynayabilecekleri hakkında öneriler sunulması gibi) feminist bir tartışma alanı yaratmanın oldukça uzağında kalmaktadır.

Ayrıca dijital annelerin web sitelerini günlük pratikleri hakkında bilgi almak amacıyla kullandıkları düşünüldüğünde, toplumsal cinsiyet ilişkilerini yansıtacak biçimde yapılandırılmış web içeriklerinin, kadının ulaştığı bilgiyi de yönlendireceği söylenebilir. Bilindiği üzere, kadınlara ebeveynlik pratikleri hakkında içerik sunan web siteleri hafta sonu çocuklarla hangi aktivitelerin yapılabileceğinden çocuklara uyku eğitiminin nasıl verilebileceğine, aile içi iletişimin nasıl olması gerektiğinden doğru okul seçimine kadar anne ve çocuk etkileşiminin birçok aşamasında kadınlara bilgi ve öneriler aktarmaktadır. $\mathrm{Bu}$ çerçevede değerlendirildiğinde ise, web sitelerinden edinilen bilginin toplumsal cinsiyet rolleri doğrultusunda yapılandırılmış olmasının, kadının günlük pratiklerini bu bilgiler doğrultusunda șekillendirmesine neden olarak sahip olunan annelik modelini de etkileyebileceğini söylemek yanlış olmayacaktır.

\subsection{Bloglar}

Annelik blogları ve blog yazarı anneler ${ }^{7}$, okuyucularına çoğunlukla kendileri hakkında olumlu ya da olumsuz deneyimlerini aktardıkları içerikler sunmaktadır. Bu bağlamda annelik bloğu olarak adlandırılan blogları; annelerin kendi çocuklarının hayatları ve kendi annelik deneyimlerine ilişkin düşüncelerini otobiyografik bir biçimde aktararak, diğer annelere tavsiyeler verdikleri dijital ortamlar olarak tanımlamak mümkündür (Lupton, 2016; Morris, 2014). Kadınların yaşam hikayelerini aktardıkları formlar olan annelik blogları, blog dünyası içerisindeki bir kültürel fenomene işaret etmeleri ve anneliğin çağdaş inşasını yansıtan ürünler olmaları bakımından önem taşımaktadır. Blogların, yazarının 'kişiliği, bakış açısı ve arzuları hakkında güçlü fikirler' verdiği düşünüldüğünde (Nardi, Schiano, Gumbrecht ve Swartz, 2004, s. 42), annelik bloglarının da blog yazarı kadının benimsediği annelik modelini ve aile içerisindeki konumunu okuyucuya aktaran dijital metinler niteliğinde olduğu söylenebilir. Bu özelliği doğrultusunda ele alındığında ise, annelik blogları, annelik rolünün, annelik kimliğinin yansıtıldığı ve anne-çocuk ilişkisinin hem toplumsal hem de dijital olarak yeniden üretildiği kültürel alanlar olarak tanımlanabilir (Orton-Johnson, 2017, s. 1). Ayrıca bloglar, annelerin kişisel deneyimleri aracılığıyla annelik modellerini aktarmalarının yanı sıra, blog okuyucularının da bu annelik yansımalarını kendi deneyimleri ve kültürel arka planları bağlamında okuyarak yeniden yorumlamalarına olanak sağlamaktadır (Powell, 2010). Bu bakımdan annelik blogları, "annelerin kendilerini nasıl tanımladıklarını ve toplumun anne olarak kendilerinden beklediklerine nasıl baktıklarını" (Gürçayır-Teke, 2018, s. 32) aktaran ortamlar olmaları bakımından aslında "kültürel olarak yapılandırılmış bir anlayışla" (Chen, 2013, s. 517) hareket etmekte ve bu nedenle annelik gerekliliklerinin tartışmaya açılması sürecinde önemli bir yer tutmaktadır.

Annelik blogları, yazarlarının anlatımları üzerinden anneliğin çeşitli versiyonlarını inşa etmekte ve bu versiyonlar okuyucular tarafından tanımlanmakta, doğrulanmakta, 
açıklığa kavuşturulmakta ve yeniden yorumlamaktadır. Böylelikle bloglar aracılığıyla, annelik kamusallaşmakta ve söylemselleşmektedir (Powell, 2010, s. 37). Bu bakımdan dijital ortamda üretilen kadın söylemlerinin içeriğinin de annelik rolünün dönüşümü açısından önemli olduğu, söylemlerin feminist bir içerik taşıyıp taşımadığına bağlı olarak geleneksel annelik rolüne ilișkin gerekliliklerin de sorgulanabileceği ifade edilebilir. Çünkü, yukarıda da değinildiği üzere, dijital ortamdaki geleneksel annelik rolü inşasının tartışmaya açılabilmesi, ancak kadınlar tarafından üretilen dijital feminist söylemlerle mümkündür. Ayrıca kadınların kendi dijital feminist söylemlerini üretebilmeleri, hem çevrimiçi hem de çevrimdışı ortamdaki annelik söylemlerinin öznesi olabilmeleri için de bir gerekliliktir. Bu bağlamda Chen (2013, s. 513), annelik bloglarının diğer blog içeriklerinin doldurmakta başarısız olduğu bir boşluğu karşıladığının altını çizmektedir. Buna göre annelik blogu yazarlığı; hem bir medya ilgisine sahip olması hem de bu blog türünün kendi adını taşıması dolayısıyla, anne bloggerlığının kendi eleștirel analizini de içeren bilgisayar aracılı kadın söyleminin bir türüdür. Benzer biçimde Powell (2010) da blogların annelerin kendi söylemlerini üretmelerine imkan tanıdığından bahsetmektedir. Araştırmacıya göre, kadınlar annelik blogları aracılığıyla hem 'iyi' hem de 'kötü' annelik ${ }^{8}$ temsiliyle karşılaşmakta; bu bakımdan tüm annelere yönelik dönüştürücü bir söylem üretebilmektedirler. Anneler, kendi hikayelerini anlatmaya teşvik edilmekte ve bu durum geleneksel olmayan annelik algısının inşa edilmesinde de önemli imkanlar sağlamaktadır.

Kadınların otobiyografik bir biçimde kişisel annelik hikayelerini aktarabildikleri mecralar olmaları dolayısıyla annelik blogları, bu hikayeler aracılığıyla okuyucuya feminist bir temsil sunulabilmesini de olanaklı kılmaktadır. Bu özellikleri nedeniyle, feminist yazarlar tarafından, annelik bloglarının direnişin alternatif alanı olduğundan bahsedilmekte ve bu blogların kadınların feminist bakış açısını ifade edebilmeleri için uygun ortamlar sağladığının altı çizilmektedir (Keller, 2012). Bu açıdan geleneksel annelik rolü içeriğini ve pratiklerini tartışmaya açabilecek potansiyele sahip olduğu varsayılan annelik bloglarının, annelik rolleri ve toplumsal geleneklerden bağımsız annelik modeli çeşitliliğinin keşfedilmesini sağlayarak (Nelson, 2010; Schoenebeck, 2013), geleneksel annelik rolünün dönüşümüne katkıda bulunacağı düşünülmektedir.

Annelik blogları, geleneksel medyada görülenden farklı bir resim çizmektedir. Söz konusu bloglarda kadınları yeni doğan bebeğinin taleplerinden bitkin düşmüș, çocuğu hasta olduğunda ne yapacağını bilemeyen ya da doğum sonrası depresyon yaşayan ve bunları okuyucularıyla paylaşan bireyler olarak görülebilmek mümkündür. Tabii bu aşamada annelik rolünü üstlenmiş kadınların bloglarda kendilerini nasıl kimlik üzerinden konumlandırmayı tercih ettikleri de ayrı bir tartışma konusu olarak karşımıza çıkmaktadır. Bu çerçevede çok sayıda araştırmacının (Chen, 2013; Lopez, 2009; Powell, 2010; Ratliff, 2009), annelik bloglarının, geleneksel medyada yer aldığının tersine, 'iyi anne' ideolojisini aktif bir biçimde reddettiğinin altını çizdikleri görülmektedir. Öyle ki Ratliff (2009) tarafından gerçekleştirilen araştırmada, infertilite blogları aracılığıyla kadınlar tarafından gösterilen tepkinin ve geleneksel medyaya taşınan bir kamusal tartışmanın yasal düzenlemeler üzerinde etkili olabilecek kadar kamuoyunun gündemine taşınabileceğinin altı çizilmektedir ${ }^{9}$. Lopez (2009, s. 729) ise, annelik bloglarının anneliğin geleneksel temsiline meydan okuyabileceğini öne sürmektedir. Annelik bloglarını radikal bir hareket olarak değerlendiren ve bu bakımdan araştırılması gerekliliğinin altını çizen Lopez (2009, s. 730-731) için, söz konusu bloglar kadınların uzun bir geçmişi olan annelik unvanıyla da ilişkili olan kimliklerini tanımlama mücadelelerinde önemli bir yer tutmakta ve anneliği çerçeveleyen geleneksel söylemi değiștirebilme potansiyeli taşımaktadır. 
Buna ek olarak, annelik bloglarındaki feminist tartışmanın sadece yazarlar değil blog okuyucuları tarafından da talep edilebildiğini söylemek mümkündür. Ayrıca bu okuyucu kitlesi, çok sayıda farklı yapısal özelliğe sahip kadın gruplarından da oluşabilmektedir. Örneğin; Gezer-Tuğrul (2018, s. 82) tarafından Türkiye'de iki farklı annelik bloğu (Reçel blog, Müslüman anneler bloğu) üzerinden gerçekleştirilen çalışmada, Reçel Blog'un, feminist söylemler ile desteklenen ve geleneksel İslam anlayışı ile örtüşmeyen radikal çıkışlarının olduğu tespit edilmiştir. Makbul kadınlık ve özelde annelik anlayışına karşı çıkan bu dijital feminist içeriğin dindar kadınlar arasında bir karşılığının olduğu yorum yapan kadınların söylemlerinden de çıkarılabilmektedir.

Annelik bloglarında üretilen feminist içeriğin yanı sıra, blog yazarlarının da geleneksel annelik rolünün tartışmaya açılması sürecinde takipçileri için birer rol model olduklarından bahsetmek mümkündür. Örneğin; Türkiye'de gerçekleştirilen bir araştırmada blogger annelerin çocuk eğitimi, çocukla kurulacak duygusal bağ, annenin hangi doğum kontrol yöntemini kullanacağı, yeni nesil annelik fikrinin benimsetilmesi gibi konularda anneleri etkileyip, yönlendirebildikleri bulgulanmıștır (Aktan ve Kayıș, 2018, s. 39). Bu çerçevede ele alındığında, geniş takipçi kitleleri bulunan bu kadınların ${ }^{10}$, blog içeriklerinde geleneksel annelik rolünü sorgulayarak tartışmaya açmalarıyla feminist tartışmanın annelik bloglarına taşınmasına olanak sağlayacaklarından bahsetmek mümkündür. Bu bağlamda Lopez (2009, s. 732) blog içeriklerinde annelik rolü gerekliliklerini sorgulayan (farkında olarak ya da olmayarak) blog yazarlarının feminist hareketi kucakladıklarından ve geleneksel annelik mitiyle mücadele ettiklerinden söz etmektedir. Blog yazarı kadınların ürettikleri içerikler aracılığıyla geleneksel annelik rolü gerekliliklerini tartışmaya açmaları, yani Powell'in (2010) ifadesiyle kötü bir annelik rolü üstlenmeleri, okuyucularına kendi kimlikleri üzerinden bir annelik modeli sunmalarına da imkan tanımaktadır. Yani blog yazarlarının kendi geleneksel olmayan annelik rollerini blog içerikleri aracılığıyla okuyucularıyla paylaşması hem okuyucuların alternatif bir annelik modelleri hakkındaki içeriklere erişmesini sağlamakta hem de başlı başına bir feminist duruşu temsil etmektedir. Dolayısıyla annelik bloğu yazarı kadınların, geleneksel annelik temsiline meydan okumaları, bu temsili yeniden yorumlayarak okuyucuların kişisel alanlarında deneyimledikleri annelik rolüne bir ses kazandırmalarını sağlamakta ve anneliğe ait pratikler hakkındaki anlatılar üzerinden anne kimliklerinin daha nüanslı ifadelerini mümkün kılmaktadır (Friedman, 2013; Lopez, 2009; Orton-Johnson, 2017). $\mathrm{Bu}$ bakımdan değerlendirildiğinde Orton-Johnson'un $(2017$, s. 1) da vurguladığ gibi, annelik bloglarını "ana akım medya anlatılarını demokratikleştirme potansiyeline sahip güçlü araçlar" olarak konumlandırmak mümkündür. Benzer biçimde, Lopez (2009) de annelik bloglarının ana akım medyadaki annelik temsiline meydan okuyan bir anne kimliğinin kültürel inşası hakkında yeni bakış açıları kazandırdığından bahsetmektedir. Ancak burada üzerinde durulması gereken nokta, her bir annelik bloğunun geleneksel annelik temsiline karşı durmadığı, ana akım medya anlatılarını demokratikleştirme potansiyeline sahip annelik bloglarının feminist içerikleri bakımından diğerlerinden ayrıldığıdır. Schuster'de (2013, s. 16) feminist içeriğe sahip blogların, düzenli olarak güncellenmeleri, güncel konular hakkında yoğun içeriklere sahip olmaları ve yorumlara yer vermeleri nedeniyle feminist hareketi destekleyecek bilginin paylaşılması ve farkındalığın arttırılması açısından önemli mecralar olduğunun altını çizmektedir.

Annelik bloglarını, anneliğin feminist inşasını gerçekleştiren önemli mecralar olarak değerlendiren araştırmacılar olduğu gibi, söz konusu blog içeriklerine kuşkuyla yaklaşan araştırmacılardan da söz etmek mümkündür. Örneğin; Chen (2013, s. 510)'anne 
bloğu' terimini ısrarla reddetmekte, söz konusu blogların 'annecilik bloğu' olduğunu söylemektedir. Araştırmacıya göre, bu 'annecilik blogları' başlı başına kadınların besleme, büyütme, bakım verme gibi rollerini pekiştirici bir niteliktedir ve bloglardaki içerik dijital evine bağlılığın bir yeni formudur. Dolayısıyla annelik blogerlığı da anneliğin bakım ve besleme özelliklerini ön plana çıkardığından ve bir ideal anne prototipi ürettiğinden dahası tüm kadınlara ya da tüm annelere genellenemeyecek bir özelliğe odaklanarak, anneliği marjinalize ettiğinden feminist bir tartışma ortamı sunmaktan oldukça uzaktır. Husbands (2008) ise, annelik bloglarını, bloglarda sunulan içeriğin geleneksel annelik rolünü sıklıkla vurgulaması nedeniyle eleștirmektedir. Bu çerçevede, hamile kadınların blogları üzerinden kendi bedenlerini nasıl sergilediklerini ve birbirlerine nasıl yorumlarda bulunduklarını inceleyen Husbands, kadınların hamile bedenlerini dijital ortamlarda paylaşmalarının geleneksel medyadaki annelik temsilinin çevrimiçi ortamdaki somutlaşmış hali olduğunu vurgulamaktadır. Çünkü kadınlar bir bakıma çevrimiçi ortamın kendilerine sunduğu imkanlardan yararlanarak, geleneksel annelik rolleri çerçevesinde sürdürdükleri hamileliklerini tarihsel bir akış içerisinde muhafaza etmekte ve çevreleriyle paylaşmaktadır. Benzer biçimde Gürçayır-Teke (2018, s. 32) tarafından Türkiye'deki annelik blogları üzerine gerçekleștirilen bir başka araştırmada blogger annelerin, blogları aracılığıyla çocuklarına dijital günlükler tuttukları, ayrıca kendileri gibi anne olan diğer kadınlarla iletişim kurarak, onların deneyimlerinden yararlandıkları ortaya koyulmuştur. Araştırmacılara göre, bu deneyim paylaşımı her ne kadar kadınların annelikte karşılaştıkları zorluklarla başa çıkmalarını kolaylaştırsa da, blogger annelerin iyi bir anne olmayı çocuk bakımı ve eğitimi konularında uzmanlaşmalarıyla birlikte düşünmeleri var olan sorumluluklarına yenilerini katmakta ve kendilerini 'yetersiz' hissetmelerine neden olmaktadır.

\section{Sonuç ve Değerlendirme}

Kadınların çevrimiçi platformlarda annelik rol ve sorumlulukları bağlamında yer almaya başlaması, dijital ortamda annelik rolü gerekliliklerine dair içerik üretimini de beraberinde getirmiştir. Çoğunlukla anneler tarafından üretilen bu içerik, dijital iletişim ortamlarını; her bir kadının benimsediği annelik rolü doğrultusunda gerçekleştirdiği anne-baba/çocuk etkileşimine yönelik pratiklerin yeniden üretildiği kültürel alanlara dönüştürmüştür. Gerçekleştirilen çalışma kapsamında ise, bu kültürel alanlarda üretilen içeriğin dijital annelik inşasının tartışmaya açılması sürecinde nasıl bir rol oynadığının ve web siteleri ve bloglar aracılığılla annelere sunulan içeriğin kadınların feminist sesini duyurmak amacıyla kullanılıp kullanılamayacağının değerlendirilmesi hedeflenmiştir. Buna göre, annelerin feminist seslerini duyurabilme olanakları çerçevesinde ele alındığında, web siteleri ve bloglarda yer alan içeriğin şu özellikleri bakımından geleneksel annelik inşasının tartışmaya açılıp açılamayacağı hakkında belirleyici olacağını söylemek olanaklıdır:

- Web siteleri ve bloglar, geleneksel annelik rolünün tartışmaya açılması sürecinde okuyucularına ürettikleri ve üretilmesine altyapısal olanak tanıdıkları dijital feminist içerik ölçüsünde katkıda bulunabilmektedir. Dolayısıyla söz konusu ortamlarda üretilen içerik (radikal annelik siteleri ve feminist annelik blogları olmak üzere) toplumsal cinsiyet rollerine dair bir sorgulamayı beraberinde getirebileceği gibi tam tersi bir etkiye de sahip olabilir. Bu bakımdan web siteleri ve blogların kullanıcılar arasında etkileşimi sağlayan yapısının varlığından çok, bu ortamlarda üretilen içeriğin ne anlattığı üzerinde durulmalıdır.

- Web siteleri ve bloglarda üretilen içerik, geleneksel annelik rolünü sorgulayacak 
bir dijital tartışma ortamına olanak sağlayabileceği gibi bu rolü pekiştirici bir görev de görebilmektedir. Bunun en temel nedenini ise, kadınların günlük sorumluluklarını oluşturan çocuk bakım ve gözetimi sürecinde üstlendikleri geleneksel ve geleneksel olmayan pratikler arasında çok ince bir çizgi bulunmasıyla açıklamak mümkündür. Yani hangi pratiklerin geleneksel hangi pratiklerin ise geleneksel olmayan annelik rolüne dahil edileceğinin sınırlarını kesin çizgilerle çizmek kolay değildir. Ayrıca, çevrimiçi ortamlarda kadınlar tarafından sunulan 'geleneksel olmayan' annelik modellerine ilişkin pratikler, beklenmedik bir biçimde kınama ya da sert eleştirilerle karşılaşabilmektedir. Kadınların çocuk için zararlı olabileceğini ya da çocuğun gelişimini olumsuz etkileyebileceğini düşündükleri bir ifadeyle karşılaştıklarında tepki göstermeleri ise, aslında 'geleneksel olmayan' annelik rolünün sınırlarını belirleyen bir kontrol mekanizması olarak değerlendirilebilir. Dahası kadınlar tepkiye karşılaşacaklarını düşündükleri içerikleri paylaşmaktan da kaçınabilmektedir. $\mathrm{Bu}$ kontrol mekanizmasının ortaya çıkışı ise, daha önce metin içerisinde de değinildiği gibi, kadınların feminist aktivizm sürecine katılmalarında caydırıcı olabilmektedir.

- Web siteleri ve bloglarda üretilen feminist içeriğin her iki mecranın birbirinden ayrılan özellikleri bakımından farklılık gösterebileceğini de eklemek gerekmektedir. Bloglarda, kadınlar, annelik rolünü blog yazarlarının kendi günlük pratikleri hakkındaki anlatıları üzerinden deneyimleyebilmektedir. Web sitelerinde ise, bloglardan farklı olarak, kadınların forumlarda paylaştıkları görüş ve düşünceleri çerçevesinde ortak bir tartışma ortamına erişme olanağı buldukları söylenebilir.

- Web siteleri ve bloglar, kadınlar arasında dijital bir kız kardeşliğin kurulmasına katkı sağlamaktadır. Ancak bu kız kardeşliğin odak noktasının ne olacağının üretilen içerikten bağımsız olduğunu söylemek mümkün değildir. Bu nedenle burada bahsedilen dijital kız kardeşlik, geleneksel annelik rolünü sorgulayarak dijital feminist bir tartışma başlatacak güce sahip olabileceği gibi, makbul annelik için gerekli rol pratiklerini birbirleriyle paylaşan bir grubu da temsil edebilir. Bu bakımdan dijital annelerin feminist sesinin yükselmesi ya da alçalmasında kadınlar arasında kurulan bu dayanışmanın neyle ilgili olduğu belirleyicidir.

- Web siteleri ve bloglarda neyin tartışmaya açlacağı kullanıcı kadınların talepleri doğrultusunda şekillenmektedir. Bu bakımdan neden her kullanıcının geleneksel annelik rolünü sorgulayan dönüştürücü bir dijital annelik söyleminin inşa edilmesini talep etmediği de gerekli bir soru olarak sorulabilir. Bu durumu, kadınların da içselleştirdiği toplumsal cinsiyet rolleriyle açıklamak mümkündür. Kendi toplumsal cinsiyet rollerini oynayan kadınlar da, en az erkekler kadar, bu rol beklentilerini karşılayacak içerik üretiminde bulunmakta, dijital iletişim ortamlarının kendilerine sunduğu görece demokratik addedilebilecek tartışma ortamını değerlendirmeyi tercih edemeyebilmektedir.

Sonuç olarak, web siteleri ve bloglar annelik rol gerekliliklerinin tartışmaya açlabilmesinde oldukça önemli bir potansiyele sahiptir. Bu bakımdan, web siteleri ve blog içeriklerinde feminist annelik modeli temsillerine ne derece yer verildiği; geleneksel annelik rolünün sorgulanacağını mı yoksa sergileneceğini mi belirleyecektir.

\section{Notlar}

1 Burada 'annelik modeli' ile ifade edilmek istenen ebeveynin çocuğu ya da eşiyle ilişkisindeki davranış örüntüsüdür. Bireyin benimsediği annelik ya da babalık modeli, onun sosyo-demografik özelliklerine, aile içerisinde benimsenen toplumsal cinsiyet rollerine, eşler arasındaki iş bölümüne ve toplumsal yapıya bağlı olarak farklılık gösterebilmektedir (Budig, Misra ve Boeckmann, 2012; Christopher, 2012; Daly, 1993; Wall, Aboim ve Marinho, 2007). 
2 Günümüzde kadınların hamile kalmadan önce ileride üstlenecekleri makbul annelik rolü için yerine getirmeleri gereken çok sayıda gereklilik olduğunu da söylemek yanlış olmayacaktır. Hamile kalmak isteyen bir kadının; fiziksel sağlğını koruması, gıda takviyelerine başlaması, hamilelik sürecine ilişkin bilgi edinmesi gibi ön hazırlıklar aracılığılla kendisini bekleyen bu sürece fiziksel ve psikolojik olarak hazır olması beklenmektedir.

3 Her ne kadar son yıllarda babaların da çocuk bakım ve gözetim sürecine aktif katılımlarının arttığını görmek mümkün olsa da, gerçekleştirilen birçok çalışma, çalışıyor olma durumlarında dahi, kadınların halen ebeveynlik rollerini birincil olarak üstlendiklerini göstermektedir. Detaylı bilgi için bkz. (1) Aldous, J., Mulligan, G.M. \& Bjarnason,T. (1998). Fathering Over Time: What Makes the Difference, Journal of Marriage and the Family, 60(4): 809-820, (2) Demo, D.H. \& Acock, A.C. (1993). Family Diversity and The Division of Domestic Labor: How Much Have Things Really Changed?, Family Relations, 42(3): 323331, (3) Shetton, B.A. \& John, D. (1993). Does Marital Status Make a Difference: Housework Among Married and Cohabiting Men and Women, Journal of Family Issues, 14(3): 401-420, (4) Yeung, W.J., Sandberg, J.F., Davis-Kean, P.E. \& Hoffreth, S.L. (2001). Children's Time with Fathers in Inact Families, Journal of Marriage and Family, 63(1): 136-154, (5) Zimmerman, T.S., Haddock, S.A., Ziemba, S. \& Rust, A. (2001). Family Organizational Labor: Who's Calling the Plays?, Journal of Feminist Family Therapy, 13(2-3), 65-90.

4 Fotopoulou (2016, s. 997) burada kadınların dijital iletişim ortamları üzerinden birbirleriyle yakın ilişki içerisinde olmaları ve yine bu ortamlar dolayısıyla feminist düşünceye olan katılım durumunun da belirgin olması bakımından kız kardeşlik düşüncesinin yeniden ortaya çıktı̆ı̆ından bahsetmektedir.

5 Schuster $(2013$, s. 8) çalışmasında çevrimiçi feminist aktivizme katııımın kuşaklararası farklııklara bağlı olarak nasıl değiştiğine odaklanmaktadır. Bu çerçevede gerçekleştirilen çalışmada genç kadınların (20-31 yaş arası) dijital iletişim araçlarına, sosyal medya ve internete daha yakın oldukları tespit edilmiştir. Diğer taraftan, dijital iletişim ortamlarını kullanmayan daha büyük yaştaki kadınların (32-70 yaş arası) dışarda kaldığı ve dolayısıyla feminizmle ilgilenme düzeyleri açııından nesiller arasında bir kopma yaşandığı sonucuna ulaşııııştı.

6 Koeber'in (2001) "radikal annelik siteleri" olarak adlandırdığı web siteleriyle genç anneler, tek ebeveynler ya da marjinal gruplara yönelik annelik ve ebeveynlikle ilgili içerik sunan web sitelerini kast etmektedir. Söz konusu radikal annelik siteleri arasında Hip Mama ya da Bad Ass Breastfeeding gibi web sitelerini saymak mümkündür.

7 Annelik bloglarında yer alan içeriğin neredeyse tamamının anneler tarafından üretildiği söylenebilir. Ancak bazı blog yazarlarının içerik üretimi sürecinde profesyonel destek aldıklarını da eklemek gerekmektedir.

8 Powell'in (2010) 'iyi' ve 'kötü' annelik tanımlaması, annelik bloglarında kadınlar tarafından aktarılan hikaye içeriklerine işaret etmektedir. Buna göre 'iyi anne', çocuğun esas bakımını üstlenen, sürekli gülümseyen ve anlayışı olan ve çocuklarına sonsuz, tükenmeyen bir sevgiyle bağlı olan anne rolünün aktarıldığı içerikleri ifade etmektedir. 'Kötü anne' olarak ifade edilen ise, söz konusu özelliklerle uyuşmayan davranışlarda bulunduğuna ilişkin içerikler üreten kadınlara karşlık gelmektedir.

9 Ratliff (2009, s. 131) tarafından gerçekleştirilen çalısma, Amerika'nın Virginia eyaletinde delege John Crosgrove tarafından önerilen, çocuk düşürme ile ilgili yasal düzenlemeyi konu almaktadır. Söz konusu yasal düzenlemeye göre, eğer medikal bir müdahale olmadan düşük gerçekleştiyse, anne bu ölümü yetkili makamlara rapor etmek zorundadır. Aksi durumda anne bu ölümün yasal sorumlusu olacak, annenin kusurlu bir davranışı olduğunun tespit edilmesi durumunda ise, cezai yaptırım uygulanabilecektir. Söz konusu yasal düzenleme önerisine kadınlar kendi çocuk düşürme hikayelerini, başta infertilite blogları olmak üzere, çok sayıda blog üzerinden okuyucularılla paylaşarak tepki göstermiş ve gelen tepkiler sonucunda söz konusu yasal düzenleme önerisi geri çekilmiştir.

10 Örneğin; blogcuanne.com yazarının Instagram'da 100.000'in, Facebook'da 69.000'in üzerinde takipçisi bulunmaktadır. Yazar ayrıca yazılı basın için de içerik üretmekte, bloğuna reklam almaktadır. Benzer biçimde, annekaz.com'un ise, Instagram'da 27.000 'in üzerinde, Facebook'da 197.000 'in üzerinde takipçisi bulunmakta, ayrıca bloğa reklam da alınmaktadır.

\section{Kaynakça}

Aktan, E. ve Kayış, H. (2018). Sosyal medya ve değişim:Bloglar aracılığıyla anneliğin evrimi üzerine netnografik bir analiz. AJIT-e: Online Academic Journal of Information Technology, 9(32), 39-54.

Aldous, J., Mulligan, G.M. \& Bjarnason, T. (1998). Fathering over time: What makes the difference. Journal of Marriage and the Family, 60(4): 809-820.

Ammari, T. ve Schoenebeck, S. (2015). Understanding supporting fathers and fatherhood on social media sites. Proceedings of the 33rd Annual ACM Conference on Human Factors in Computing Systems (s. 1905-1914). New York: ACM Conference. 
Bradly, E. ve Guerin, S. (2010). Not the romantic, all happy, coocy coo experience: A qualitative analysis of interactions on an Irish parenting web site. Family Relations, 59(1), 14-27.

Budig, M., Misra, J. ve Boeckmann, I. (2012). The motherhood penalty inb cross-national perspective: The importance of work-family policies and cultural attitudes. Social Politics, 19(2), 163-193.

Chen, G. (2013). Don't call me that: A techno-feminist critique of the term mommy blogger. Mass Communication and Society, 16(4), 510-532.

Christopher, K. (2012). Extensive mothering Employed mothers' constructions of the good mother. Gender \& Society, 26(1), 73-96.

Crossley, A. (2015). Facebook feminism: Social media, blogs, and new technologies of contemporary U.S. feminism mobilization. An International Quarterly, 20(2), 253268.

Daly, K. (1993). Reshaping fatherhood: Finding the models. Journal of Family Issues, 14(4), 510-530.

Demo,D.H. \& Acock, A.C. (1993). Family diversity and the division of domestic labor: How much have things really changed?. Family Relations, 42(3): 323-331.

Fotopoulou, A. (2016). Digital and networked by default?: Women's organizations and the social imaginary of networked feminism. New Media \& Society, 18(6), 9891005.

Friedman, M. (2013). Mommy blogs and the changing face of motherhood. Toronto: University of Toronto Press.

Gezer-Tuğrul, Y. (2018). Dindar kadınların annelik algısı: Reçel blog ve Müslüman anneler bloğunun karşılaştırmalı analizi. Fe Dergi, 10(2), 71-84.

Gibson, L. ve Hanson, V. (2013). Digital motherhood: How does technology help new mothers? Proceedings of the SIGCHI Conference on Human Factors in Computing Systems (s. 313-322). New York: ACM Press.

Gül-Ünlü, D. (2019). Web sitelerinde ebeveynlere sunulan içerik toplumsal cinsiyet rollerinden bağımsız olabilir mi?: 'Bebek.com' web sitesi örneği. Fe Dergi, 11(2), 24-37.

Gürçayır-Teke, S. (2018). Dönüşen anneliğe yönelik netnografik bir Analiz: Blogger anneler. Milli Folklor, 26(103), 32-47.

Husbands, L. (2008). Blogging the maternal: Self-representations of the pregnant and postpartum body. Culture \& Social Justice, 32(2), 68-79.

Johnson, S. (2015). Intimate mothering publics: Comparing face-to-face support groups and internet use for women seeking information and advice in transition to firsttime motherhood. Culture, Health \& Sexuality, 17(2), 237-251.

Kaya, Ş. (2018). Kadın ve sosyal medya. Gaziantep Üniversitesi Sosyal Bilimler Dergisi, 17(2), 563-576.

Keller, J. (2012). Virtual feminisms: Girl's blogging communities, feminist activism and participatory politics. Information, Communication \& Society, 15(3), 429-447. 
Koeber, A. (2001). Postmodernism, resistance, and cyberspace: Making rhetorical spaces for feminist mothers on the web. Women's Studies in Communication, 24(2), 218240.

Lopez, L. (2009). The racial act of mommy blogging: Redefining motherhood through the blogosphere. New Media \& Society, 11(5), 729-747.

Lupton, D. (2016). The use and value of digital media for information about pregnancy and Early Motherhood: A Focus Group Study. BMC Pregnancy and Childbirth, 16(1), 171-181.

Lupton, D. ve Pedersen, S. (2016). An Australian survey of women's use of pregnancy and parenting apps. Wolmen and Birth, 29(4), 368-375.

Lupton, D., Pedersen, S. ve Thomas, G. (2016). Parenitng and digital media: From the early web to contemporary digital society. Sociology Compass, 10(8), 730-743.

Madge, C. ve O'Connor, H. (2005). Mothers in the making? exploring liminality in cyber/ space. Trnasactions of the Institute of British Geographers, 30(1), 83-97.

Madge, C. ve O'Connor, H. (2006). Parenting gone wired: Empowerment of new mothers on the internet? Social \& Cultural Geography, 7(2), 199-220.

Martland, N. ve Rothbaum, F. (2006). Thinking critically about the internet: Suggestions for Practitoners. Child Welfare, 85(5), 837-852.

Miller, T. (2010). Annelik duygusu: Mitler ve deneyimler. İstanbul: İletişim Yayınları.

Morris, M. (2014). Social networking site use by mothers of young children. Proceeidings of the 17th ACM Conference on Computer Supported Cooperative Work \& Social Computing (s. 1272-1282). New York: ACM Press.

Nardi, A., Schiano, D., Gumbrecht, M. ve Swartz, L. (2004). Why we blog. Communications of the ACM, 41-46.

Nelson, M. (2010). Parenting our of control: Anxious parents in uncertain times. New York: New York University Press.

Orton-Johnson, K. (2017). Mummy blogs and representation of motherhood: "Bad mummies" and their readers. Social Media + Society, 3(2), 1-17.

Pedersen, S. (2014). Is it friday yet?: Mothers talking about sex online. Cyberpsychology, $8(2), 2-4$.

Pedersen, S. ve Lupton, D. (2016). What are you feeling right now?: Communities of maternal feeling on mumsnet. Emotion, Space, and Society, 26, 1-7.

Pedersen, S. ve Smithson, J. (2013). Mothers with attitude- how the mumsnet parenting forum offers space for new forms of feminity to emerge online. Women's Studies International Forum, 38, 97-106.

Philips, N. ve Broderick, A. (2014). Has mumsnet changed me? SNS influence on identity adaptation and consumption. Journal of Marketing Management, 30(9-10), 10391057.

Powell, R. (2010). Good mothers, bad mothers and mummy bloggers: Rhetorical Resistance and Fluid Subjectivities. MP: An Online Feminist Journal, 2(5), 37-50. 
Radey, M. ve Randolph, K. (2009). Parenting sources: How do parents differ in their efforts to learn about parenting. Femily Relations, 58, 536-548.

Rashley, L. (2005). Work it out with your wife: Gendered expectations and parenting rhetoric online. NWSA Journal, 17(1), 58-92.

Ratliff, C. (2009). Policing miscarriage: Infertility blogging, rhetorical enclaves, and the case of house bill 1677. WSQ: Women's Studies Quarterly, 37(1), 125-145.

Schoenebeck, S. (2013). The secret life of online moms: Anonymity and disinhibition on youbemom. 7th International AAAI Conference on Weblogs and Social Media (s. 8892). Boston: AAAI Conference.

Schuster, J. (2013). Invisible feminists? social media and young women's political participation. Political Science, 65(1), 8-24.

Sever, M. (2014). Kadınlık, annelik, gönüllü çocuksuzluk: Elisabeth Badinter'den kadınlık mı annelik mi?; Tina Miller'dan annelik duygusu; Mitler ve deneyimler ve Corinne Maier'den no kid üzerinden bir karşılaştırmalı okuma çalışması. Fe Dergi, 7(2), 72-86.

Shetton, B.A. \& John, D. (1993). Does marital status make a difference: Housework among married and cohabiting men and women. Journal of Family Issues, 14(3): 401-420.

Wall, K., Aboim, S. ve Marinho, S. (2007). Fatherhood, family and work in men's lives: Negotiating new and old masculinities. Recherches Sociologiques et Anthropologiques, 38(2), 105-122.

Yeung, W.J., Sandberg, J.F., Davis-Kean, P.E. \& Hoffreth, S.L. (2011). Children's time with fathers in inact families. Journal of Marriage and Family, 63(1): 136-154.

Zimmerman, T.S., Haddock, S.A., Ziemba, S. \& Rust, A. (2001). Family organizational labor: Who's calling the plays?. Journal of Feminist Family Theraphy, 13(2-3): 6590. 


\title{
Feminist Voice of Digital Mothers: The Role of Web Sites and Blog Contents in Opening Motherhood Construction to Discussion
}

\author{
Derya Gül Ünlü (Asst. Prof. Dr.)
}

\section{Extended Abstract}

Women's increasing participation in digital communication media due to their needs related to motherhood roles is accompanied by the production of content on the predetermined requirements of motherhood role, thereby carrying the construction of motherhood to digital media and diversifying motherhood models. As women start to produce content about maternity practices on digital media, such digital media each has turned into a presentation of motherhood model where suggestions related to appropriate motherhood role are provided, and new domains that bring forward suggestions about motherhood practices have emerged. Based on this perspective, the study aims to address the question of whether women produce content, which may contribute to the transformation of women's position in gender relations, or the content produced serves to be a medium, which reinforces current gender practices for women. In accordance with this aim, within the framework of literature review, the functionality of such discussion platforms, which is provided to women through the means of web sites and blogs, is interrogated in terms of whether it is used as a medium on which women can make themselves heard.

The fact that women exchanging ideas on their shared experiences on websites and online discussion rooms can bring along a feminist question of motherhood is because mothers have the opportunity to experience the maternal roles of other women. Thanks to sharing and exchanging ideas with each other, mothers have the opportunity to see their motherhood experience from different perspectives, get various advice on their problems, and observe different versions of motherhood through the sharing of other users (Johnson, 2015; Madge \& O'Connor, 2005; Pedersen \& Lupton, 2016; Philips \& Broderick, 2014). In this case, it becomes important that the content related to motherhood practices conveyed by women in these environments has a function to reinforce the motherhood model. Because, as opposed to questioning gender roles, the exemplary motherhood model, where women advise each other about how to behave, can also serve as a reinforcing task. For this reason, it would not be wrong to say that websites with content that is contrary to the traditional representation of motherhood will be able to transform expectations regarding the role of motherhood.

Through motherhood blogs, women have had the opportunity to open up individual motherhood role constructions for public debate. Today, the content of motherhood blogs is produced by mothers in a public environment and immediately answered by mothers or non-mothers. Maternity blogs build versions of motherhood, and those versions are defined, verified, clarified, and reinterpreted by readers. Thus, motherhood in motherhood blogs becomes public and discursive (Powell, 2010, p. 37). In this respect, it can be said that the content of women's discourses produced in the digital environment is also important in terms of the transformation of the motherhood role, and depending on whether the discourses contain a feminist content, the requirements 
of the traditional motherhood role can be discussed. In other words, the unconventional role of motherhood can be constructed only through the produced feminist digital discourses and women can become the subjects of their discourses about motherhood by producing their own feminist discourses. In this context, Chen (Chen, 2013, p. 513), highlights that motherhood blogs meet a gap that other blog content has failed to fill. Accordingly, mother blogging is a type of computer-mediated women's discourse that includes both its own critical analysis of mother blogging, as it has both a media interest and this blog genre has its own name. Similarly, Powell (2010) mentions that blogs allow mothers to produce their own discourses. Accordingly, women encounter both "good" and "bad" maternity representation through maternity blogs, and in this respect, they produce a transformative discourse for all mothers. In this way, mothers are encouraged to tell their own stories, and this situation provides important opportunities in building an unconventional motherhood perception.

In conclusion, it should be said that digital communication environments are very important channels for diversifying digital motherhood representations by allowing women who have adopted different maternity models to share their daily practices with each other. For this reason, it is seen that the diversification of the feminist motherhood model representations in the content of motherhood practices on websites and blogs will be determinant in questioning or exhibiting the traditional motherhood role.

Keywords: Digital Communication, Digital Motherhood, Web Site, Blog, Feminist Activism.

Bu makale intihal tespit yazılımlarıyla taranmışır. Intihal tespit edilmemiştir.

This article has been scanned by plagiarism detection softwares. No plagiarism detected.

Bu çalışmada "Yükseköğretim Kurumları Bilimsel Araştırma ve Yayın Etiği Yönergesi" kapsamında uyulması belirtilen kurallara uyulmuştur.

In this study, the rules stated in the "Higher Education Institutions Scientific Research and Publication Ethics Directive" were followed. 